\title{
A szikes talajok javítóanyag-szükségletének becslésére alkalmas módszerek összehasonlítása
}

\section{FILEP GYÖRGY}

Debreceni Egyetem, Agrártudományi Centrum, Mezőgazdaságtudományi Kar, Debrecen

A szikes talajok javításának célja, a nagymértékben felhalmozódott Naionok és vízoldható Na-sók mennyiségének csökkentése, s ezáltal a talaj kedvezőtlen kémiai és fizikai állapotának megszüntetése. Az eredményes javitás feltétele:

a) a kolloidokon adszorbeált Na-ionok kicserélése (helyettesítése) Ca-ionokkal, megfelelö mértékben oldódó talajjavító anyag alkalmazásával,

b) a szikesedést okozó Na-források (a felszínhez közeli szikes-sós talajvíz, szikes öntözö- és/vagy csurgalékvizek) további hatásának megszüntetése,

c) a lecserélt Na-ionok és az oldható Na-sók eltávozásának (a kilúgzás feltételeinek) biztosítása altalajlazítással, s szükség szerint, a talajvíz szintjének szabályozásával.

A javulási folyamat egyszerüsített reakciósémáját az 1. ábra mutatja.

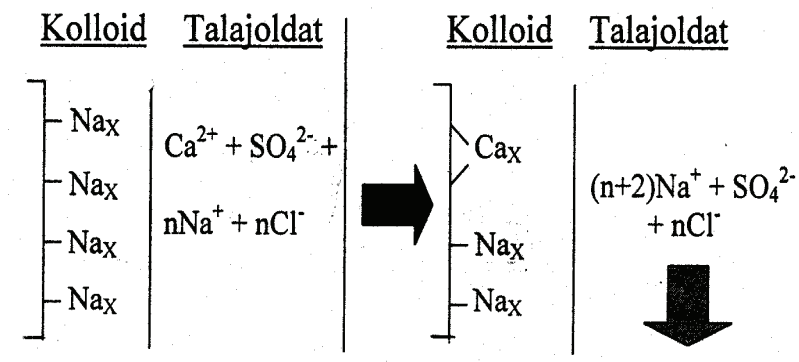

1. ábra

A Na-Ca kationcsere vázlata szikes talajok gipszezése esetén (az x index az adszorbeált kationokat jelöli)

* A Magyar Talajtani Társaság és a Magyarhoni Földtani Társulat Mérnökgeológiai Szakosztálya 2000. február 9-én, a szikesedés témakörében rendezett előadóülésén elhangzott előadás anyaga 


\section{Anyag és módszer}

A javitóanyag-dózis számitása:

- a talaj kicserélhető vagy mozgékony (kicserélhető+oldatban levő) Na-tartalma alapján, illetve

- a szuszpendált talajrészecskék koagulációját előidéző gipszoldat mennyiségéből kiindulva történhet.

A javasolt megoldások közül az értékeléshez a viszonylag egyszerü, gyors, $\mathrm{s}$ a hazai szaktanácsadásban is jól ismert módszereket választottuk ki. Ezek receptúrája az általánosan használt módszerkönyvekben is megtalálható (ARANY, 1953, 1962; HERKE, 1962; RÉDLYNÉ, 1988).

A mozgékony Na-tartalom mérésére és a gipszadag becslésére használt egyszerü módszerek

a) A mozgékony Na-tartalom (me/100 g) meghatározása $\mathrm{NH}_{4}$-acetátos módszerrel (RICHARDS, 1954; THOMAS, 1984). A kicserélö oldat 1 mol/liter koncentrációjú, 7 pH-jú $\mathrm{NH}_{4}$-acetát oldat. (A hazánkban preferált, módosított Mehlich-eljárást nemzetközileg kevésbé használják).

b) A mozgékony $\mathrm{Na}^{+}$-ionok $(\mathrm{me} / 100 \mathrm{~g})$ mennyiségének meghatározása HERKE (1962) szerint. A kicserélő oldat 0,5 $M\left(\mathrm{NH}_{4}\right)_{2} \mathrm{CO}_{3}$. A talajt a kicserélö oldattal egyensúlyba hozzuk, majd a szuszpenziót szürjük. A szürlet bepárlása után, a következő lépés a száraz maradék feloldása desztillált vízben, s a desztillált vizes oldat titrálása $\mathrm{HCl}$-dal.

c) SCHOONOVER (1952) módszer. A kicserélő oldat telített gipszoldat. A szikes talajt az ismert Ca-tartalmú telített gipszoldattal egyensúlyba hozzuk (a talaj:gipszoldat aránya $=1: 20$ ), majd mérjük az egyensúlyi szürlet Ca-koncentrációját. A gipszoldat Ca-ionjai lecserélik a talaj adszorbeált Na-ionjait. Így az eredeti telített, és a talajjal egyensúlyba hozott (egyensúlyi) gipszoldat $\mathrm{Ca}^{2+}$-tartalmának különbsége, a lecserélt Na-ionok mennyiségével egyenértékü.

d) A kicserélhető $\mathrm{Na}^{+}$mennyiségének meghatározása ANTIPOV-KARATAJEV és MAMAEVA (1955) szerint. A Schoonover módszer egyik változata. A kicserélő oldat szintén telített gipszoldat (a talaj:kicserélő oldat aránya $=1: 40$ ).

e) A gipszadag becslése ülepitéses módszerrel, ARANY $(1953,1962)$ szerint. A javítandó talajból $5 \mathrm{db}$ mérőhengerbe 5-5 g-ot mérünk be. A sorozat tagjaihoz $25-25 \mathrm{~cm}^{3}$ desztillált vizet, majd rendre növekvő mennyiségü telített gipszoldatot adunk, végül mindegyik minta térfogatát $100 \mathrm{~cm}^{3}$-re egészítjük ki desztillált vízzel. Összerázás után a szuszpenziót kb. 14-16 órán át állni hagyjuk. A javítóanyag-szükségletet a sorozatnak az a tagja mutatja, amelyik állás közben éppen kitisztul.

A vizsgálatokhoz a Tiszántúl különböző helyeiről származó réti szolonyec és (kisebb részben) szoloncsák-szolonyec talajok B-szintjéből vett mintákat használtunk. 


\section{Eredmények és értékelés}

Bár a semleges és gyengén savanyú feltalajú szikesek javítása $\mathrm{CaCO}_{3}$-tartalmú anyagokkal (meszezéssel) történik, a javulást ezeknél is az adszorbeált $\mathrm{Na}$-ionok $\mathrm{Ca}^{2+}$ általi helyettesítésére lehet visszavezetni. A további számításokban ezért a gipsz-szükséglelet tekintjük alapnak, mivel a $\mathrm{CaCO}_{3} \mathrm{t} / \mathrm{ha}=0,58$ $\mathrm{CaSO}_{4} \cdot 2 \mathrm{H}_{2} \mathrm{O}$ t/ha.

A gipszadagok számitása a kicserélhetö, ill. a mozgékony Na-tartalom alapján (FILEP, 1980)

a) Gipszadag/m²

$$
\mathrm{CaSO}_{4} \cdot 2 \mathrm{H}_{2} \mathrm{O} t / \mathrm{m}^{2}=\frac{\mathrm{Na}_{\mathrm{X}} \cdot \mathrm{A} \cdot \mathrm{M} \cdot \rho \cdot \mathrm{E}}{100000},
$$

ahol $N a_{x}$ a talaj kicserélhetö Na-tartalma me/100 g; $A$ a terület $\mathrm{m}^{2}$-ben kifejezve; $M$ a javítandó réteg vastagsága, méter; $\rho=$ a talaj térfogattömege $\mathrm{g} / \mathrm{cm}^{3}$, ill. $\mathrm{t} / \mathrm{m}^{3}$; $E$ a gipsz egyenértéktömege $=86,1$.

b) A gipszadag 1 ha-ra $\left(10000 \mathrm{~m}^{2}-r e\right)$ :

$$
\mathrm{CaSO}_{4} \cdot 2 \mathrm{H}_{2} \mathrm{O} \text { t/ha }=\mathrm{Na}_{\mathrm{x}} \cdot \mathrm{M} \cdot \rho \cdot 86,1 / 10
$$

c) Csökkentett gipszadag. A gyakorlatban nem mindig szükséges és nem is célszerü az adszorbeált Na-ionok teljes lecserélésére törekedni, mivel a $\mathrm{Na}^{+}$egy részét nagy adagok alkalmazásával sem lehet teljesen kicserélni. A javítóanyagszükséglet számításánál ezért az alábbi megoldás is választható.

A talaj eredeti kicserélhető Na-tartalmának $\left(\mathrm{Na}_{\mathrm{x}}^{\mathrm{e}}\right)$ ismeretében - figyelembe véve a talaj adszorpciós tulajdonságait és a szabadföldi kísérletek eredményeit - számítható a javítás után megkívánt adszorbeált Na-tartalom $\left(\mathrm{Na}_{\mathrm{x}}^{\mathrm{j}}\right)$ Mindkét adatot kifejezhetjük abszolút értékben (me/100 g egységekben), vagy relatív értékben (az összes kicserélhetö bázikus kation [S], vagy a kationcsere kapacitás $[\mathrm{T}] \%$-ában). Általában arra kell törekedni, hogy a talaj $\mathrm{Na}_{\mathrm{x}} \%$-a javítás után legalább $5 \%$-ra csökkenjen.

Így a javítóanyag-szükséglet a

$$
\mathrm{CaSO}_{4} \cdot 2 \mathrm{H}_{2} \mathrm{O}(\mathrm{t} / \mathrm{ha})=\left[\frac{\mathrm{Na}_{\mathrm{x}}^{\mathrm{e}} \%-\mathrm{Na}_{\mathrm{x}}^{\mathrm{j}} \%}{100} \cdot \mathrm{T}\right] \cdot \mathrm{M} \cdot \rho \cdot \mathrm{E} / 10
$$

(3) képlet szerint is számítható; ahol $\mathrm{Na}_{\mathrm{x}} \%=\mathrm{Na}_{\mathrm{x}} \cdot 100 / \mathrm{T}$; azaz $\mathrm{Na}_{\mathrm{x}}=\frac{\mathrm{Na}_{\mathrm{x}} \%}{100} \cdot \mathrm{T}$. 
Lúgos talajoknál $\mathrm{T} \sim \mathrm{S}$; $e$ a nem javított talaj; $j$ a javított talaj jele; $T$ a talaj kationcsere kapacitása me/100 g.

d) A gipszadag számitása az Arany szerinti ülepitéses módszerrel kapott adatokból. A számításnál figyelembe vesszük egyrészt azt, hogy a gipsz oldhatósága szobahőmérsékleten kb. $2 \mathrm{~g} /$ liter $\left(2 \mathrm{mg} / \mathrm{cm}^{3}\right)$, másrészt azt, hogy (ha a térfogattömeg 1,5) $1 \mathrm{~m}^{3}$ talaj tömege $1500 \mathrm{~kg}$, azaz 1 ha terület $20 \mathrm{~cm}$-es rétegében 3 millió $\mathrm{kg}=3000 \mathrm{t}$ talaj van. Ezért a kísérleti elõírást betartva, $1 \mathrm{~cm}^{3}$ telített gipszoldat 1,2 t/ha gipszadagnak felel meg.

\section{Összefüggésvizsgálatok}

$\mathrm{Az}$ ismertetett módszerekkel kapott eredményeket, a standard módszernek tekintett ammónium-acetátos eljárással mért $\mathrm{Na}_{\mathrm{x}}$-ből számított gipszadagokhoz hasonlítva értékeltük.

Jelölések:

$\mathrm{Y}=\mathrm{CaSO}_{4} \cdot 2 \mathrm{H}_{2} \mathrm{O}$ t/ha, az $\mathrm{NH}_{4}$-acetátos módszerrel mért $\mathrm{Na}_{\mathrm{x}}$-böl számítva;

$\mathrm{X}=$ a vizsgált gyors módszerek alapján számított $\left(\mathrm{CaSO}_{4} \cdot 2 \mathrm{H}_{2} \mathrm{O}\right.$ t/ha) értékek.

I. A Schoonover módszerrel mért $\mathrm{Na}_{\mathrm{x}}$-ből kiindulva:

$$
\mathrm{Yt} / \mathrm{ha}=1,1 \mathrm{X}-3,3 ; \quad \mathrm{r}=0,96 ; \quad \mathrm{r}^{2}=0,922
$$

II. A Herke módszerével mért $\mathrm{Na}_{\mathrm{x}}$ értékkel kapott összefüggés:

$$
\mathrm{Y} \mathrm{t} / \mathrm{ha}=1,266 \mathrm{X}-5,39 ; \quad \mathrm{r}=0,94 ; \quad \mathrm{r}^{2}=0,884
$$

III. Az Antipov-Karatajev és Mamaeva szerint mért kicserélhető $\mathrm{Na}^{+}$alapján:

$$
\mathrm{Y} t / \mathrm{ha}=1,215 \mathrm{X}-3,85 ; \quad \mathrm{r}=0,94 ; \quad \mathrm{r}^{2}=0,884
$$

IV. Az Arany szerinti ülepítés eredményeit figyelembe véve:

$$
\mathrm{Y} t / \mathrm{ha}=0,415 \mathrm{X}+13,2 ; \quad \mathrm{r}=0,6 ; \quad \mathrm{r}^{2}=0,360
$$

A (4)-(7) egyenlet grafikus megjelenítése a 2. ábrán látható. Az egyenletekből és a 2. ábrából kitünik, hogy az ammónium-acetátos módszer adataival legjobban a Schoonover módszer eredményei korreláltak. A Herke, ill. az AntipovKaratajev és Mamaeva szerint mért kicserélhető Na-tartalom (és gipsz-szükséglet) a kisebb mértékben szikes talajoknál kisebb, a kifejezetten szikes talajoknál viszont nagyobb értékeket adott, mint a standard módszer. Az Arany szerinti ülepítéses eljárással pedig a többi módszerétől jelentősen eltérő eredményeket kaptunk. Ennek magyarázatához abból lehet kiindulni, hogy a kolloidtartalmú szikes talajszuszpenziók kitisztulását (a részecskék gyorsított ülepedését) előidéző Ca-sóoldat legkisebb mennyisége, az ún. kritikus elektrolitkoncentráció értéke, számos tényezőtől függ. A legfontosabbak: 


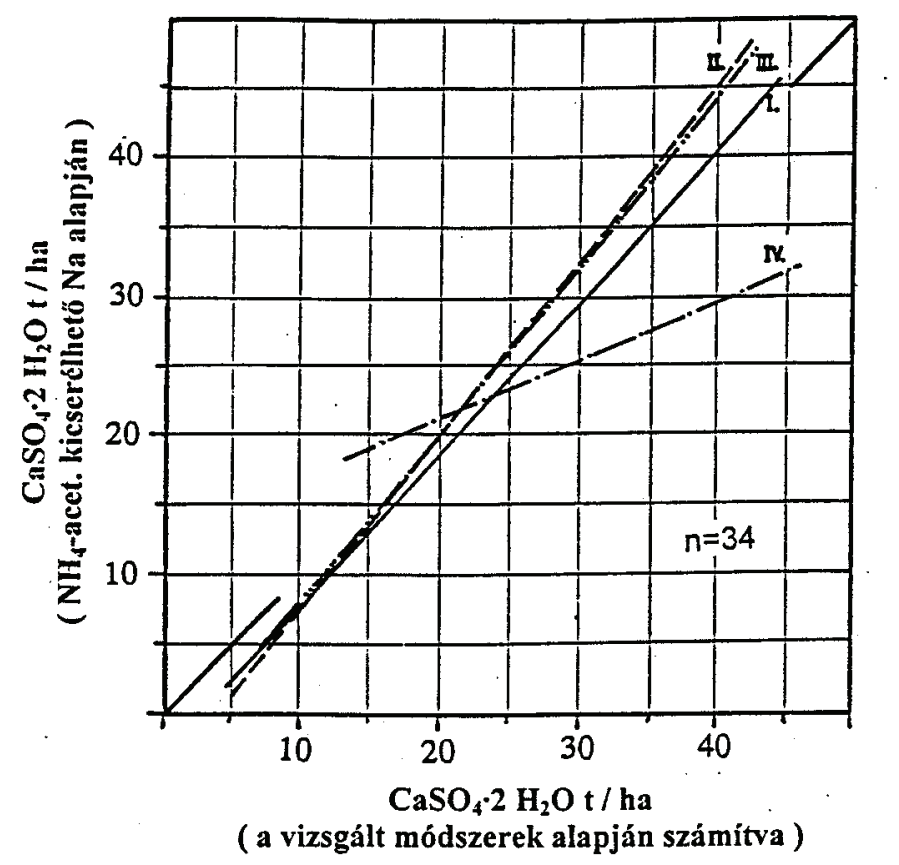

2. ábra

A különböző módszerekkel kapott, és az ammónium-acetátos módszer alapján számított gipszadagok közötti kapcsolat. I. Schoonover, II. Herke, III. Antipov-Karatajev és

Mamaeva, IV. Arany szerint mérve

- a szuszpenzió kolloidtartalma/kolloidkoncentrációja,

- a kolloidok minősége (az illit, montmorillonit, klorit, vermikulit agyagásványok, a vas- és mangán-oxidhidroxidok, illetve a lebegő humuszkolloidok egymáshoz viszonyított aránya),

- a kolloidok Na-telítettségének mértéke,

- a talaj oldható sótartalma és a sók minősége, valamint

- az ülepítési kísérlet időtartama (a beállítástól az értékelésig eltelt idő).

Másrészt a talaj javulását elöidéző folyamatok mechanizmusa (az adszorbeált Na-ionok kicserélődése Ca-ionokra, a szerves anyagok kalciumtelítettségének növekedése, a szerves és ásványi komponensek közötti $\mathrm{Ca}^{2+}$-hidak kialakulása) jóval összetettebb, mint az egyszerü koaguláció, s a változás a talaj egész tömegére csak fokozatosan terjed ki. Fentiekből kitünik, hogy az ülepítéses modellvizsgálatok alapján sem a kicserélhető Na-ionok részarányára, sem a talajok javítás utáni állapotára nem lehet következtetni. Ezért koagulációs próba nem helyettesítheti a pontosabb, gyors (és elméletileg alátámasztott) eljárásokat. A gyakorlati munkák egyszerúsítése céljából több évtizeddel ezelőtt be- 
vezetett tájékoztató vizsgálatok (közöttük a javítóanyag-dózis becslésére javasolt ülepítés) alkalmazását, akkor az tette indokolttá, hogy egyes talajjellemzők számszerüsítésére nem álltak rendelkezésre kielégítően gyors vizsgálati módszerek, ill. néhány komponens (pl. a Ca- és Mg-koncentráció) közvetlen mérésére nem voltak megfelelő müszerek. Az ülepítéses módszerek hiányosságait érezve, már ARANY $(1953,1962)$ is hangsúlyozta, hogy ezek „további kidolgozásra és ellenőrzésre szorulnak".

Vizsgálataink szerint, gyakorlati célokra elsősorban a Schoonover módszer javasolható.

Bár a szikes talajok többségének javítása a bevált eljárásokkal megoldható, ökonómiai szempontból jelenleg csak a szikes jellegü (szolonyeces) réti talajok, a vastagabb A-szintű szolonyec talajok és a jó talajú táblákban előforduló szikes foltok javítása látszik indokoltnak.

\section{Összefoglalás}

A szikes talajok javítóanyag-szükségletének becslésére használható néhány gyors módszer megbízhatóságát vizsgáltuk. Úgy találtuk, hogy a standardnak tekintett ammónium-acetátos eljárással mért kicserélhető nátriumtartalomból kiinduló számítás eredményeivel, a Schoonover módszer mutatta a legszorosabb összefüggést. A Herke, illetve az Antipov-Karatajev és Mamaeva szerint mért kicserélhető nátrium mennyisége (és a gipsz-szükséglet), a kisebb mértékben szikes talajoknál kisebb, a kifejezetten szikes talajoknál viszont nagyobb értékeket adott, mint a standard módszer. Az Arany-féle ülepítéses eljárás pedig a többi módszerétől jelentősen eltérő eredményekhez vezetett.

Gyakorlati célokra tehát, elsősorban az egyszerüen kivitelezhető Schoonover módszert lehet ajánlani.

\section{Irodalom}

Antipov-KaratajeV I. N. \& Mamaeva L. JA.., 1955. Dosztüpnüh laboratornüh metodah opredelenija sztepeni szoloncevatoszti pocsv. Pocsvovedenie. (1) 61-65.

ARANY S., 1953. A szikes talajok javításához szükséges anyag mennyiségének megállapítása. In... Talajvizsgálati módszerkönyv. (Szerk.: BALLENEGGER R.) 223234. Mezőgazdasági Kiadó. Budapest.

ARANY S., 1962. Szikes és sós talajok vizsgálata javitási szempontból. In: Talaj- és trágyavizsgálati módszerek. (Szerk.: BALLENEGGER R. \& DI GLéRIA J.) 222-240. Mezőgazdasági Kiadó. Budapest.

FiLEP GY., 1980. Talajtan (szakmérnököknek). DATE. Debrecen.

HERKE S., 1962. A kicserélhető $\mathrm{Na}^{+}$meghatározása ammónium-karbonáttal. In: Talajés trágyavizsgálati módszerek. (Szerk.: BALLENEGGER R. \& DI GLÉRIA J.) 139. Mezőgazdasági Kiadó. Budapest. 
Richards, L A. (Ed.) 1954. Diagnosis and Improvement of Saline and Alkali Soils. USDA Handbook No 60. USDA. Washington, D. C.

RÉDLY L.-NÉ, 1988. A talajok kationcserélő tulajdonságainak meghatározási módszerei. In: Talaj- és agrokémiai vizsgálati módszerkönyv. (Szerk.: BUZÁS I.) 2. 103-108. Mezőgazdasági Kiadó. Budapest.

SCHOONOVER, W. R., 1952. Examination of soils for alkali. Univ. California Extension Service. Berkeley, CA.

Thomas, G. W., 1984. Exchangeable cations. In: Methods of Soil Analysis. Part 2. (Ed.: PAGE, A. L.) 159-165. Agronomy No 9. Madison, WI

Érkezett: 2001. március 5. 